\title{
Bacteria urinary tract infection in HIV-infected children and adolescents in Abuja, Nigeria: a cross-sectional study
}

\author{
${ }^{1}$ Okechukwu, A. A., and ${ }^{2}$ Thairu, Y.
}

Departments of ${ }^{1}$ Paediatrics and ${ }^{2}$ Microbiology, University of Abuja Teaching Hospital, Gwagwalada, Abuja, Nigeria Correspondence to: nebokest@yahoo.com; +2348036719906

\section{Abstract:}

Background: Urinary tract infection (UTI) remains the second commonest opportunistic infections among HIV infected children. This study was conducted to determine the prevalence and causative bacteria of UTI in HIV infected children and adolescents on antiretroviral medications in our health institution.

Method: The study was a cross sectional design conducted between October 2017 and March 2018 among HIV infected children and adolescents aged 2 months to 18 years on follow up attendance at the Paediatric Outpatient Special Treatment Clinic (POSTC) of University of Abuja Teaching Hospital (UATH). Early morning midstream urine was collected from each participant for urinalysis, microscopy and aerobic bacterial culture. Bacteria were identified from culture by standard microbiological methods and antibiogram of the isolates was determined by the disk diffusion method.

Result: Of 166 HIV infected children and adolescents studied, 106 (63.9\%) were males, 82 (49.4\%) were in age group 5-10 years, and $110(66.3 \%)$ were from lower socio-economic class. Significant bacteria (UTI) were isolated in $54(32.5 \%)$ subjects, with $38(70.4 \%)$ from females, and 51 (94.4\%) from those on first line antiretroviral therapy. Isolates recovered were Escherichia coli 20 (37.0\%), Klebsiella pneumoniae 16 (29.6\%), Staphylococcus aureus $8(14.8 \%)$, Pseudomonas aeruginosa $6(11.1 \%)$, and Proteus mirabilis 4 (7.4\%). Leucocyturia in 19 $(35.2 \%)$, nitrituria in $10(18.5 \%)$, and haematuria in $15(27.8 \%)$ subjects with significant bacteriuria were also recorded. Isolates were sensitive to ofloxacin $(81.5 \%)$, nalidixic acid $(74.1 \%)$ and cefuroxime $(61.1 \%)$, while they were resistant to cotrimoxazole $(100 \%)$, ampicillin $(98.1 \%)$ and piperacillin $(94.4 \%)$. Significant difference was observed in the mean CD4 cell count and viral load of subjects with significant bacteriuria compared to those without; $838.6 \pm 177.8$ versus $1009.9 \pm 234.7$ cells/ $\mu \mathrm{L}(p=0.02)$, and $10,360.5 \pm 471.0$ versus $5,840.8 \pm 563.8$ copies $/ \mathrm{ml}(p=0.003)$ for CD4 cell count and viral load respectively.

Conclusion: This study reported a high prevalence of UTI among HIV infected children and adolescents, especially in those with high viral load. Routine screening for UTI should be offered to HIV infected children and adolescents with high viral load.

Keywords: HIV, urinary tract infection, children, adolescents

Received March 4, 2019; Revised June 22, 2019; Accepted July 13, 2019

Copyright 2019 AJCEM Open Access. This article is licensed and distributed under the terms of the Creative Commons Attrition 4.0 International License (http://creativecommmons.org/licenses/by/4.0), which permits unrestricted use, distribution and reproduction in any medium, provided credit is given to the original author(s) and the source.

\section{Infection des voies urinaires par des bactéries chez des enfants et des adolescents infectés par le VIH à Abuja, au Nigeria: étude transversale}

\author{
${ }^{1}$ Okechukwu, A. A., et ${ }^{2}$ Thairu, $Y$. \\ Départements de ${ }^{1}$ pédiatrie et ${ }^{2}$ microbiologie, Hôpital universitaire de Abuja, Gwagwalada, Abuja, Nigeria \\ Correspondance à: nebokest@yahoo.com; +2348036719906
}




\section{Abstrait:}

Contexte: L'infection des voies urinaires (UTI) reste la deuxième infection opportuniste la plus répandue chez les enfants infectés par le VIH. Cette étude a été menée pour déterminer la prévalence et la bactérie causale des infections urinaires chez les enfants et les adolescents infectés par le VIH prenant des antirétroviraux dans notre établissement de santé.

Méthode: L'étude était une conception transversale menée entre octobre 2017 et mars 2018 chez des enfants et des adolescents infectés par le VIH âgés de 2 mois à 18 ans et suivis à la Clinique de traitement spécial pour enfants ambulatoires (POSTC) de I'Hôpital universitaire de Abuja (UATH)). Des échantillons d'urine, de microscopie et de cultures bactériennes aérobies ont été recueillis chez chaque participant. Les bactéries ont été identifiées à partir de cultures par des méthodes microbiologiques standard et l'antibiogramme des isolats a été déterminé par la méthode de diffusion sur disque.

Résultat: Sur 166 enfants et adolescents infectés par le VIH étudiés, 106 (63,9\%) étaient des hommes, 82 $(49,4 \%)$ étaient âgés de 5 à 10 ans et $110(66,3 \%)$ appartenaient à la classe socio-économique inférieure. Des bactéries significatives (UTI) ont été isolées chez 54 sujets $(32,5 \%)$, dont $38(70,4 \%)$ de femmes et 51 (94,4\%) de celles sous traitement antirétroviral de première intention. Les isolats récupérés étaient Escherichia coli 20 $(37,0 \%)$, Klebsiella pneumoniae $16(29,6 \%)$, Staphylococcus aureus $8(14,8 \%)$, Pseudomonas aeruginosa 6 $(11,1 \%)$ et Proteus mirabilis $4(7,4 \%)$. Une leucocyturie chez 19 sujets $(35,2 \%)$, une nitriturie chez $10(18,5 \%)$ et une hématurie chez 15 sujets $(27,8 \%)$ présentant une bactériurie importante ont également été enregistrés. Les isolats étaient sensibles à l'ofloxacine $(81,5 \%)$, à l'acide nalidixique $(74,1 \%)$ et au céfuroxime $(61,1 \%)$, tandis qu'ils étaient résistants au cotrimoxazole (100\%), à l'ampicilline (98,1\%) et à la pipéracilline (94,4\%). Une différence significative a été observée entre le nombre moyen de cellules CD4 et la charge virale des sujets présentant une bactériurie significative par rapport à ceux ne présentant pas; 838,6 $\pm 177,8$ par rapport à 1009,9 $\pm 234,7$ cellules/ $\mu \mathrm{L}(p=0,02)$ et $10,360,5 \pm 471,0$ par rapport à $5840,8 \pm 563,8 \mathrm{copies} / \mathrm{ml}(p=0,003)$ pour le nombre de cellules CD4 et la charge virale, respectivement.

Conclusion: Cette étude a révélé une prévalence élevée d'UTI chez les enfants et les adolescents infectés par le $\mathrm{VIH}$, en particulier chez ceux ayant une charge virale élevée. Un dépistage systématique des infections urinaires doit être proposé aux enfants et aux adolescents à charge virale élevée infectés par le VIH

Mots-clés: VIH, infection des voies urinaires, enfants, adolescents

\section{Introduction:}

Globally over 3.4 million children are living with human immunodeficiency virus (HIV) infection at the end of 2011, 91\% of which are in sub-Saharan Africa, which harbors only $10 \%$ of the world's population $(1,2)$. Kidney disease is a widely recognized frequent complication of HIV infection and often manifests as HIV associated nephropathy (HIVAN), urinary tract infections (UTI), electrolyte abnormalities, among others $(3,4)$. UTI is defined as the presence of bacterial growth of greater than $10^{5}$ colony forming units per $\mathrm{ml}$ in a clean-catch, mid-stream voided urine sample, or greater than $10^{3}$ organisms per $\mathrm{ml}$ in a catheter or supra-pubic aspirated urine. UTI is the second most common infection in children (5).

Urinary tract is a unique sterile space lined with transitional mucosa cells and usually impermeable to microorganisms. However, infection occurs when pathogenic organisms enter the space and subsequently adhere to its mucosal lining (5). The mechanisms of entrance are either through retrograde ascent of fecal-perineal bacteria from the host bowel or nosocomial following instrumentation, or as part of a systemic infection $(5,6)$. Gender, age, race, circumcision, and immune status of individuals are host factors that affect the incidence and bacterial adherence in UTI (5, $6)$.

Notable urinary pathogens causing UTI include Gram-negative rods (Escherichia coli, Citrobacter spp, Enterobacter spp), Gramnegative cocci (Neisseria gonorrheae), Grampositive cocci (Staphylococcus aureus, Staphylococcus saprophyticus), and other pathogens such as Candida albicans, and Chlamydia trachomatis $(5,6)$. This risk of UTI is high in women, infants, elderly, and people with spinal cord injuries, urinary catheters, diabetes, immunodeficiency, and underlying urologic abnormalities $(7,8,9,10)$.

The hallmark of HIV infection is the profound immunosuppression that results from continued depletion of CD4 cells. This immune deficient state predisposes the individual to a wide variety of opportunistic infections (OIs) and renal syndromes that causes neurologic complications leading to urinary stasis and ultimately UTI $(11,12)$. The incidence of UTI in HIV population is clearly related to infection and immune function, as determined by lymphocytes CD4+ cells count. UTI is one of the most common bacterial infections associated with morbidity and hospitalization in HIV infected individuals (13).

Available literature on UTI and HIV/AIDS however showed conflicting reports, 
with some authors reporting higher frequency of UTI among HIV cohorts especially adult population, $(14,15)$ while others reported no significant impact of the disease on the incidence of UTI $(16,17)$. Asharam et al., (16) found no significant impact of HIV/AIDS on bacterial UTI among infected children aged 012 years in South Africa, which was similar to the report of O'Regan et al., (17) in Canada. However in Nigeria, Ibadin et al., reported high frequency of UTI in adolescent and young adult patients with advanced WHO clinical stages (18). Kaplan et al., (15) also reported high incidence of UTI (20.0\%) among his AIDS cohort.

Because of paucity of information on incidence of UTI among HIV children in this part of the country, this study was conducted to determine the prevalence and aetiological agents of UTI among HIV-infected children and adolescents on highly active antiretroviral therapy (HAART) at a tertiary health institution in Abuja, Nigeria, with the aim that these findings will provide insight on the magnitude of the problem among infected children and adolescents in our environment.

\section{Methodology:}

\section{Study setting and design}

A cross sectional study was carried out at the Paediatric Outpatient Special Treatment Clinic (POSTC) of the University of Abuja Teaching Hospital (UATH) between October 2017 to March 2018. POSTC is an out-patient clinical service area where HIV infected children and exposed babies are seen and followed up for treatment/monitoring. It has consulting rooms for the doctors, nurses, and adherence counselors. Record clerks, Pharmacists and nutritionists are also at their disposal on week days (Monday-Friday, from $7.30 \mathrm{am}$ to $4 \mathrm{pm}$.).

UATH is a 350 bed capacity referral hospital, sub-serving the people of Federal Capital Territory, Abuja and five neighbouring states. It is one of the first centers to start offering free HIV/AIDS services in the country in 2005, through the President Emergency Plan for AIDS Relief (PEPFAR).

\section{Subjects}

The subjects were paediatric HIV infected patients between the ages 2 months and 18 years diagnosed either by serological method or by polymerase chain reaction (PCR) test, and started on anti-retroviral (ARV) therapy. Consecutive eligible children attending the POSTC were recruited and subsequently enrolled into the study after parents/caregivers provided written informed consent, and children 7 years and above provided written inform assent.

Inclusion criteria for the study were; HIV infected children and adolescents from 2 months to 18 years of age on ARV therapy, patients/caregivers/children residing within FCT Abuja for easy collection of early morning urine, parents/caregivers acceptance to be part of the study, and older children who gave assent for the study. Exclusion criteria include those unwilling to participate in the study, exposed babies, those residing outside FCT, and patients with other forms of nephropathy such as nephrotic syndrome, acute glomerulonephritis and others. Ethical clearance was obtained from the Ethics Committee of the health institution before the commencement of the study.

\section{Specimen collection}

Clinical and physical examinations were carried out on each subject after enrollment by the attending physician. All the subjects were then given plastic universal sterile transparent container with screw cap, and oral and written instructions were provided for each subject or their parents/guardians on the method of urine collection.

Early morning clean catch specimens of midstream voided urine were collected. For the female subjects, they were instructed to clean their genitalia from anterior to posterior in a unidirectional manner with the labial held apart, and for the infants, the parent/caregiver were advised to hold the child on the laps with the genitals exposed prior to collection. The urine samples were delivered to the laboratory within one hour of collection.

Blood sample was also collected for $\mathrm{CD}^{+}$T-cell (CD4) and viral load (VL) estimation from those subjects who have not had these estimated in the last 3 months preceding the study.

\section{Bacterial cultures and identification}

Each urine specimen was first examined macroscopically and then divided into two equal volumes. The first was used for urinalysis and Gram's staining, while the second volume was centrifuged at $3000 \mathrm{rpm}$ for 5 minutes, and used for urine microscopy and inoculation of Blood and Cysteine Lactose Electrolyte Deficient (CLED) agar plates. Calibrated wire loop delivering $0.002 \mathrm{ml}$ of the centrifuged urine was used to inoculate the 
culture media. The cultures were incubated at $37^{\circ} \mathrm{C}$ for $18-24$ hours aerobically. After overnight incubation, colony number and characteristics on the agar plates were determined, and then Gram stained. Colonies that were Gram positive on CLED were further characterized using conventional biochemical scheme of catalase, coagulase and novobiocin disc tests, while those with Gram negative reaction were characterized using the indole, motility, methyl red, Voges-Proskauer and citrate utilization (iMMVPC) tests.

The presence of at least one Gram positive or negative bacteria per oil-immersion field in the uncentrifuged urine or colony count of greater than $10^{5} \mathrm{CFU} / \mathrm{ml}$ of urine from the overnight culture on Blood agar plate was considered significant bacteriuria. Positive nitrite on urinalysis and presence of pus cells were considered features suggestive of UTI.

\section{Antibiotic susceptibility testing}

Antibiotic susceptibility of each isolate along with control strains (Staphylococcus aureus ATCC 29213, Escherichia coli ATCC 25922, Pseudomonas aeruginosa ATCC 27853 and Enterococcus faecalis ATCC 29212) was determined using the Muller-Hinton agar media by the disk diffusion method. Three to five pure colonies of similar appearance of each isolate and the control strains were emulsified in $4 \mathrm{ml}$ sterile saline. The inoculum suspension was standardized by comparing the turbidity with 0.5 McFarland standards. Muller-Hinton agar plate was streaked with the inoculum suspension using sterile swab, and antibiotic discs were placed on each agar plate after 5 minutes using sterile forcep. Within 30 minutes of applying the discs, the plates were incubated at $35^{\circ} \mathrm{C}$ for 18 to 24 hours, following which the test and the control agar plates were examined, and the diameters of zone of inhibition (in $\mathrm{mm}$ ) were measured with a ruler.

The zone diameters of inhibition of the antibiotics for the control strain were first compared with the CLSI standards and if within the acceptable limits, the zone diameters for the test isolates were then compared with CLSI zone diameter breakpoints, and result interpreted as sensitive, intermediate or resistance.

\section{CD4 cell count \& viral load estimation} The CD4 cell count was measured using automated Partec Cyflow easy count kit (Partec code no. 05-8401, Western Germany), and viral load (VL) measurement was done with Roche Smp/prep/cobs Taqman 96, USA.

\section{Data analysis}

Data were analysed using SPSS version 21.0 and results presented in frequency tables, percentages, means and standard deviations. The test for association between variables was done with the student t-test. A $p$ value $<0.05$ was considered significant.

\section{Results:}

Table 1 shows the demographic distribution of the 166 subjects, comprising $106(63.9 \%)$ males, $82(49.4 \%)$ in age group $5-<10$ years, 114 (68.7\%) were Christian, 110 (66.3\%) from low socio-economic class, and $142(85.5 \%)$ on $1^{\text {st }}$ line ART. The mean CD4 cell count was $894.5 \pm 449.1$ cells $/ \mu l$, and mean VL was $9,136.1 \pm 306.0$ copies $/ \mathrm{ml}$.

The characteristic of the study population with and without isolates is shown in Table 2. Bacteria were isolated from urine of $54(32.5 \%)$ subjects; Escherichia coli in 20 (37.0\%), Klebsiella pneumoniae 16 (29.6\%), Staphylococcus aureus $8(14.8 \%)$, Pseudomonas aeruginosa $6(11.1 \%)$, and Proteus mirabilis 4 (7.4\%). Leucocyturia, nitrituria, and haematuria were reported in $19(35.2 \%), 10$ $(18.5 \%)$, and $15(27.8 \%)$ subjects with urinary bacterial isolates respectively.

Sixteen $(29.6 \%)$ isolates were recovered from subjects in age group $10-15$ years, $38(70.4 \%)$ from females, $36(66.7 \%)$ from Christians, and 31 (57.4\%) from subjects in low socio economic class. There was no significant difference in socio-economic status $(p=0.303)$, age group $(p=0.744)$, religion $(p=0.699)$, and leucocyturia, nitrituria or haematuria $(p=0.64)$ between subjects with urinary isolates and those without isolates. There was however a significant difference in the CD4 cell count $(838.6 \pm 177.8$ vs $1009.9 \pm 234.7$ cells $/ \mu \mathrm{l}, p=0.02)$ and viral load $(10,360.5 \pm 471.0$ vs $5,840.8 \pm 563.8$ copies $/ \mathrm{ml}$, $p=0.003$ ) between subjects with urinary isolates compared to those without isolates, and subjects on $1^{\text {st }}$ and $2^{\text {nd }}$ line medication $(p=0.024)$, and gender $(p=0.03)$. 
Table 1: Demographic and clinical characteristics of the study population

\begin{tabular}{|c|c|c|c|}
\hline Characteristics & Male (\%) & Female (\%) & Total (\%) \\
\hline Number of Subjects & $106(63.9)$ & $60(36.1)$ & $166(100)$ \\
\hline \multicolumn{4}{|l|}{ Age group (years) } \\
\hline$<5$ & $7(53.8)$ & $6(46.2)$ & $13(7.8)$ \\
\hline $5-<10$ & $55(67.1)$ & $27(32.9)$ & $82(49.4)$ \\
\hline $10-15$ & $34(61.8)$ & $21(38.2)$ & $55(33.1)$ \\
\hline$>15$ & $10(62.5)$ & $6(37.5)$ & $16(9.6)$ \\
\hline \multicolumn{4}{|l|}{ Religion } \\
\hline Christianity & $78(68.4)$ & $36(31.6)$ & $114(68.7)$ \\
\hline Islam & $28(53.8)$ & $24(46.2)$ & $52(31.3)$ \\
\hline \multicolumn{4}{|l|}{ Socioeconomic class } \\
\hline High & $15(68.2)$ & $7(31.8)$ & $22(13.3)$ \\
\hline Middle & $24(70.6)$ & $10(29.4)$ & $34(20.4)$ \\
\hline Low & $67(60.9)$ & $43(39.1)$ & $110(66.3)$ \\
\hline \multicolumn{4}{|l|}{ ARVT } \\
\hline $2^{\text {nd }}$ line & $14(58.3)$ & $10(41.7)$ & $\begin{array}{c}142(85.5) \\
24(14.5)\end{array}$ \\
\hline \multicolumn{4}{|l|}{ Weight, CD4 and Viral Load } \\
\hline Weight $(\mathrm{kg})$ & $* 30.1 \pm 11.5$ & $* 31.52 \pm 13.7$ & $30.6 \pm 12.3$ \\
\hline CD4 (cells/ $\mu \mathrm{l})$ & $* 882.0 \pm 435.0$ & $* 916.6 \pm 475.9$ & $894.5 \pm 449.1$ \\
\hline Viral Load (copies/ml) & $* 10,158.75 \pm 332.6$ & $* 7,360.5 \pm 257.6$ & $9,136.1 \pm 306.0$ \\
\hline
\end{tabular}

ARVT $=$ Anti-retroviral therapy; $*$ Values are mean \pm SD

Table 2: Characteristics of subjects with and without urinary isolates

\begin{tabular}{|c|c|c|c|c|}
\hline Characteristics & $\begin{array}{c}\text { With isolates } \\
(\%)\end{array}$ & $\begin{array}{c}\text { Without isolates } \\
(\%)\end{array}$ & Total (\%) & $p$ value \\
\hline Total Number & $54(32.5)$ & $112(67.5)$ & $166(100)$ & \\
\hline \multicolumn{5}{|l|}{ Age group (years) } \\
\hline$<5$ & $4(7.4)$ & $9(8.0)$ & $13(7.8)$ & 0.744 \\
\hline $5-<10$ & $13(24.1)$ & $55(49.1)$ & $82(49.4)$ & \\
\hline $10-15$ & $16(29.6)$ & $39(34.8)$ & $55(33.1)$ & \\
\hline$>15$ & $7(13.0)$ & $9(8.0)$ & $16(9.6)$ & \\
\hline \multicolumn{5}{|l|}{ Gender } \\
\hline Male & $16(29.6)$ & $90(80.4)$ & $106(63.8)$ & 0.031 \\
\hline Female & $38(70.4)$ & $22(19.6)$ & $60(36.2)$ & \\
\hline \multicolumn{5}{|l|}{ Religion } \\
\hline Christianity & $36(66.7)$ & $78(69.6)$ & $114(68.7)$ & 0.699 \\
\hline Islam & $18(33.3)$ & $34(30.4)$ & $50(31.3)$ & \\
\hline \multicolumn{5}{|l|}{ Socioeconomic status } \\
\hline High & $9(16.7)$ & $13(11.6)$ & $22(13.3)$ & 0.303 \\
\hline Middle & $14(25.9)$ & $20(17.9)$ & $34(20.4)$ & \\
\hline Low & $31(57.4)$ & $79(70.5)$ & $110(66.3)$ & \\
\hline \multicolumn{5}{|l|}{ ARVT } \\
\hline $1^{\text {st }}$ line & $51(94.4)$ & $91(81.3)$ & $142(85.5)$ & 0.024 \\
\hline $2^{\text {nd }}$ line & $3(5.6)$ & $21(18.8)$ & $24(14.5)$ & \\
\hline \multicolumn{5}{|l|}{ Types of isolates } \\
\hline Escherichia coli & $20(37.0)$ & - & $20(12.1)$ & \\
\hline Klebsiella pneumoniae & $16(29.6)$ & - & $16(9.6)$ & \\
\hline Staphylococcus aureus & $8(14.8)$ & - & $8(4.8)$ & \\
\hline Pseudomonas aeruginosa & $6(11.1)$ & - & $6(3.6)$ & \\
\hline Proteus mirabilis & $4(7.4)$ & - & $4(2.4)$ & \\
\hline Leucocyturia & $19(35.2)$ & $3(2.7)$ & $22(13.3)$ & 0.64 \\
\hline Nitrituria & $10(18.5)$ & $1(0.9)$ & $11(6.6)$ & \\
\hline Haematuria & $15(27.8)$ & $4(3.6)$ & $19(11.4)$ & \\
\hline Weight (kg) & $* 31.4 \pm 8.6$ & $* 30.2 \pm 7.3$ & $30.6 \pm 12.3$ & 0.54 \\
\hline CD4 (cells/ $\mu \mathrm{l}))$ & $* 838.6 \pm 177.8$ & $* 1009.9 \pm 234.7$ & $894 \pm 449.1$ & 0.02 \\
\hline Viral Load ( copies/ml) & $* 10,360.5 \pm 471.0$ & $* 5,840.8 \pm 563.8$ & $9,136 \pm 306.1$ & 0.003 \\
\hline
\end{tabular}


Table 3: Antibiotic susceptibility of isolates from subjects with urinary tract infection

\begin{tabular}{|c|c|c|c|c|c|c|}
\hline $\begin{array}{l}\text { Antibiotic } \\
\text { sensitivity }\end{array}$ & $\begin{array}{l}\text { E. coli }(\%) \\
(n=20)\end{array}$ & $\begin{array}{c}\text { K. pneumoniae }(\%) \\
(\mathrm{n}=16)\end{array}$ & $\begin{array}{c}\text { S. aureus }(\%) \\
(n=8)\end{array}$ & $\begin{array}{c}\text { Ps. aeruginosa (\%) } \\
(n=6)\end{array}$ & $\begin{array}{l}\text { P. mirabilis }(\%) \\
(\mathrm{n}=4)\end{array}$ & $\begin{array}{c}\text { Total }(\%) \\
(n=54)\end{array}$ \\
\hline Ofloxacin & $18(90)$ & $14(87.5)$ & $7(87.5)$ & $5(83.3)$ & $3(75)$ & $44(81.5)$ \\
\hline Augmentin & $3(15)$ & $7(43.8)$ & $2(25)$ & $3(50.0)$ & $3(50)$ & $19(35.2)$ \\
\hline Cefuroxime & $12(60)$ & $11(68.8)$ & $5(62.5)$ & $4(66.7)$ & $1(25)$ & $33(61.1)$ \\
\hline Nalidixic acid & $15(83.3)$ & $12(75)$ & $6(75.5)$ & $5(83.3)$ & $2(50)$ & 40 (74.1) \\
\hline Gentamicin & $9(45)$ & $7(43.8)$ & $3(37.5)$ & $2(33.3)$ & $2(50)$ & $23(42.6)$ \\
\hline Tetracycline & 0 & 0 & 0 & 0 & 0 & 0 \\
\hline \multicolumn{7}{|l|}{$\begin{array}{l}\text { Antibiotic } \\
\text { resistance }\end{array}$} \\
\hline Cotrimoxazole & $20(100)$ & $16(100)$ & $8(100)$ & $6(100)$ & $4(100)$ & $54(100)$ \\
\hline Ampicillin & $19(95)$ & $16(100)$ & $8(100)$ & $6(100)$ & $4(100)$ & $53(98.1)$ \\
\hline Amoxycillin & $18(90)$ & $15(93.8)$ & $8(100)$ & $6(100)$ & $3(75)$ & $50(92.6)$ \\
\hline Erythromycin & $16(80)$ & $12(75.0)$ & $7(87.6)$ & $5(83.3)$ & $3(75)$ & $43(79.6)$ \\
\hline Piperacillin & $20(100)$ & $15(93.8)$ & $8(100)$ & $4(66.7)$ & $4(100)$ & $51(94.4)$ \\
\hline
\end{tabular}

The susceptibility patterns of the isolates are shown in Table 3 . While ofloxacin, nalidixic acid and cefuroxime were the most effective antibiotics invitro with 44 (81.5\%), 40 $(74.1 \%)$, and $33(61.1 \%)$ of the isolates respectively sensitive to them, augmentin and tetracycline were the least effective with 19 $(35.2 \%)$ and $0(100 \%)$ isolates respectively, sensitive to them. The isolates were largely resistant to cotrimoxazole 54 (100\%), ampicillin $53(98.1 \%)$, and piperacillin 51 (94.4\%).

Ofloxacin was the most effective antibiotic invitro with $18(90.0 \%)$ E. coli, 14 $(87.5 \%)$ K. pneumoniae, and 7 (87.5\%) $S$. aureus isolates sensitive to it. Tetracycline was the least effective with no isolate sensitive to it, while $9(45.0 \%)$ E. coli, 7 (43.8\%) K. pneumoniae, 3 (37.5\%) S. aureus, 2 (33.3\%) $P$ s. aeruginosa, and $2(50.0 \%)$ P. mirabilis were sensitive to gentamicin.

\section{Discussion:}

This study shows a high prevalence rate of $32.5 \%$ for UTI among HIV-infected children and adolescents on follow up visit to the Paediatric Outpatient Special Treatment Clinic of University of Abuja Teaching Hospital, Abuja, Nigeria. This was far lower than $96.6 \%$ reported among HIV infected children aged 012 years in South Africa by Asharam et al., (16). The difference between the two studies might be due to the study design and nature of the patients in the two groups. While the South African study was a retrospective one carried out among symptomatic hospital patients with culture-proven UTI, the present study was a cross sectional survey of HIV patients on outpatient routine clinic visit. The prevalence in our study was however comparable to figures obtained from HIV infected children and adults in other centers and other countries; $24.7 \%$ in children from Lagos (19), 22.2\% among HIV children (20), 23.2\% among adults in Poland (21), 48.7\% among adults from South Africa (11), 40.4\% among adults in Nigeria (22), and $57.3 \%$ from another Nigerian study among adult population (23). The rate in our study was also higher than the rates reported from other studies among HIV infected children; 9.5\% from Zimbabwe (24), $16.8 \%$ from Jamaica (3), $13.2 \%$ from Romania (25), 6.3\%, $10.3 \%$ and $6.8 \%$ from other studies from Nigeria $(18,26,27)$.

The high prevalence of UTI among HIV infected children and adolescents in this study require further evaluation for clinical significance. This is important because of attendant risk of developing renal scarring from pyelonephritis and long term complication of hypertension and chronic kidney disease. The reason for the high prevalence of UTI in this study might be due to the practice of discontinuation of chemoprophylaxis with cotrimoxazole in HIV patients whose immunity has remarkably improved. This practice is common in other centers, and appeared logical as suggested by Imamura from Japan (28). Co-trimoxazole is generally recommended in HIV infected patients for prevention of opportunistic infections (OIs). HAART is equally the most effective approach in prevention of OIs however, OIs are still occurring in patients on HAART, especially those who accessed care late (28). The late access to care might be the case of patients in this study which though showed a good immunological response (mean CD4 cell counts of $894.5 \pm 449.1$ cells $/ \mu l$ ) but still had evidence of UTI.

Subjects with isolates in their urine had significantly lower CD4 cell count and higher VL than those without isolates; $838.6 \pm 177.8$ vs $1009.9 \pm 234.7$ cells $/ \mu l(p=0.02)$ for CD4 cell 
count, and $10,360.5 \pm 471.0$ vs $5,840.8 \pm 563.8$ copies $/ \mathrm{ml},(p=0.003)$ for VL. This is similar to findings of other studies where significantly lower CD4 cell count and WHO stage 3 and 4 clinical disease consistent with high $\mathrm{VL}$, was observed in infected children and adults with UTI $(21,29,30)$. Iduoriyekemwen et al., (26) however did not make such observations among their study cohort in Nigeria. The reason for the significant difference in CD4 cell count and VL of those with and those without isolates in their urine might be related to late recognition of virological failure that may have occurred in those on $1^{\text {st }}$ line ARV medications as subjects on $1^{\text {st }}$ line drugs were observed to have significant isolates in their urine. Okechukwu and Amajuoyi (31) in their 9 year review of ART failure among HIV infected children in the same study center observed as much as $15.9 \%$ to have failed $1^{\text {st }}$ line ART. This virological failure may go on for several years before immunological and clinical failures become evident with risk of OIs.

$\mathrm{VL}$ monitoring is the state-of-the-art monitoring of patients on ART. This test is to be done at least every 3-4 months after the initial test at diagnosis. Due to high cost, VL and resistant testing are not usually done in many HIV centers in resource limited settings like ours hence patients who fail virologically may be missed for a long time before they are switched to 2nd line medication. Recently though, regular VL monitoring has been institutionalized in our center.

Urinary pathogens were significantly isolated more in females than males (70.4\% vs $29.6 \%, p=0.031$ ) in the present study. This is consistent with findings of other studies in both children and adults; $17.7 \%$ vs $7.0 \%$ among HIV children from Lagos (19), $75.0 \%$ vs $25.0 \%$ by Iduoriyekemwen et al., (26) in children from Benin, $42.8 \%$ vs $10.2 \%$ among uninfected children from Lagos (32), $89.5 \%$ vs $10.4 \%$ by Iweriobor et al., (12) among adults from South Africa, $90 \%$ vs $10 \%$ by Ibadin et al., (18) among adolescents and young adults in Nigeria, and $6.6 \%$ vs $4.8 \%$ among infected children and adults in Jos, Nigeria by Sheyin et al., (33). The reasons for higher prevalence of UTI in female subjects as previously established are related to short length of female urethra and the close proximity of vagina to anal orifice. This anatomical profile of female gender enhances retrograde ascent of fecal-perineal bacteria, increase peri-urethral colonization and easy contamination of enteric organisms from rectum to the urinary tract (5, $6)$. Also absence of prostatic fluid in females which tend to decrease colonization in male because of its bacteriostatic property may also contribute to higher prevalence of UTI in females $(6,34)$. Decreased incidence of UTI in males could also be due to wide practice of circumcision in male especially among the Christian which formed $68.7 \%$ of the subjects in this study. This singular practice in males does not only reduce colonization of the urethral opening with enteric organisms, but also reduce the risk of UTI (25).

The frequency of isolated bacteria from urine in our study compared favourably with those from other HIV studies in both children and adults across the globe $(12,16-27)$. These uropathogens easily get access to the urinary space through retrograde ascent from the host's bowel $(5,6)$ but could also result from nosocomial cause or from haematogenous seeding from distant sites. While ofloxacin, nalidixic acid and cefuroxime were the most effective antibiotics invitro for the uropathogens in the present study, cotrimoxazole, ampicillin and piperacillin were the least effective. Similar patterns have been observed among isolates in different studies on HIV infected children and adults (12, 16-27).

Leucocyturia is referred to as the presence of white blood cells (WBC) in urine, which can easily be detected using a dipstick urinalysis in a reaction that is based on the presence of leucocyte esterase, an enzyme found in azurophilic granules of monocytes and granulocytes. Bacteria and epithelial cells of the urinary tract do not contain esterase hence a positive leucocyte esterase test in dipstick urinalysis implies an inflammation and not necessarily an infection. Leucocyturia is abnormal, although some experts believe that observation of more than 5 WBC per high power field (HPF) is indicative of pathological leucocyturia. However, UTI is more likely when leucocyturia is associated with bacteriuria. In the present study, $35.2 \%$ of the subjects with isolates in their urine had leucocyturia, an association that is strongly in support of UTI. This is similar to $33.3 \%$ leucocyturia reported by Dondo et al (24) among their cohorts.

Nitrituria is the presence of nitrite in the urine, which is usually absent in normal urine. Nitrite is produced by the reductive effect of enzyme reductase on nitrate in the urine. This enzyme is produced by nitrite producing organisms such as Enterobacter, Citrobacter, Klebsiella, E. coli, Ps. aeruginosa and $P$ mirabilis when present in the urine (35). In the present study, nitrituria was seen in $18.5 \%$ of subjects with positive isolates in the urine signifying presence of nitrite producing organisms which constituted $85.2 \%$ of isolates 
in urine of subjects in this study. Dondo et al (24) in their study however observed only one among 21 subjects with isolates in their urine to have positive nitrite test, though nitrate producing organisms constituted $78.8 \%$ of isolates in their study.

Haematuria is defined as the presence of 5 or more red blood cells (RBC) per high power field (HPF) in two consecutive fresh, centrifuged specimens obtained at least one week apart (36). The dipstick urinalysis method is the commonest method for detection of haematuria in urine and has been reported to be $100 \%$ sensitive and $99 \%$ specific in detecting 5-10 RBC/HPF (5-10 $\mathrm{RBC} / \mu \mathrm{l}$ of urine or $0.015 \mathrm{mg} / \mathrm{dl}$ of haemoglobin). Haematuria can originate from any part of the kidney as injury to the uroepithelium such as irritation, inflammation or invasion by organism can result in haematuria. In the present study, $27.8 \%$ of subjects with isolates in their urine had positive dipstick urinalysis. However microscopy was not conducted for the presence of red cell cast, dysmorphic RBC or acanthocytes to determine if the haematuria is of glomerular or tubular origin or from other parts of the urinary tract.

\section{Conclusion}

There is high prevalence of UTI among HIV infected children and adolescents on outpatient follow up at the University of Abuja Teaching Hospital, Abuja, Nigeria. This is more likely to occur in subjects with high VL. Routine urine screening with dipstick urinalysis and culture for evidence of UTI are recommended for HIV infected children and adolescents with high viral load for early diagnosis.

\section{References}

1. World Health Organization. Treatment of children living with HIV. Global Health Sector Strategy in HIV/AIDS, 2011-2015. Available from:

http://www.unaids.org/en/media/unaids/content assets/documents/epidemiology/2012/gr2012/JC4 34_WorldAIDSd_results_en.pdf.

2. UNAIDS. Global report: UNAIDS report on the global AIDS epidemic 2010. Available from: http://www.unaids.org/globalreport/Global_report .htm.

3. Steel-Duncan, J., Miller, J. M., Pierre, R. B., Dunkley-Thompson. J., Palmer, P., Evans-Gilbert, T., Rodriquez, B., Christie., C. D. C., Kingston Paediatric and Perinatal HIV/AIDS Study Group. Renal manifestations in HIV-infected Jamaican children. West Indian Med J. 2008; 57 (3):

4. Ramsuran, D., Bhimma, R., Ramdial, P. K., et al. The spectrum of HIV-related nephropathy in children. Pediatr Nephrol. 2012; 27 (5): 821-827.
5. Jian, F., Linda, M., and Shortliffe, D. Urinary tract infection in children: etiology and epidemiology. Urol Clin N Am. 2004; 31: 517-526

6. Sharma, S. Current understanding of pathogenic mechanisms in UTI. Ann Natl Acad Med Sci. 1997; 33 (1): 31-38.

7. Jackson, S. L., Boyko, E. J., Scholes, D., Abraham, L., Gupta, K., and Fihn, S. D. Predictors of urinary tract infection after menopause: a prospective study. Am J Med. 2004; 117 (12): 903-911.

8. Nelson, J. M., and Good, E. Urinary tract infections and asymptomatic bacteriuria in older adults. Nurse Pract. 2015; 40 (8): 43-58.

9. Foxman, B. Epidemiology of urinary tract infections: incidence, morbidity, and economic costs. Dis Mon. 2003; 49 (2):53-70.

10. Mladenovic, J., Veljovic, M., Udovicic, I., et al. Catheter-associated urinary tract infection in a surgical intensive care unit. Vojnosanit Pregl. 2015; 72 (10): 883-888.

11. Staiman, V. R., and Lowe, F. C. Urologic problems in patients with acquired immunodeficiency syndrome. Scientific World Journal. 2004; 4 Suppl 1: 427-437.

12. Iweriobor, B. C., Obi, C. L., and Akenyemi, O. Uropathogens isolated from HIV infected patients from Limpopo Province, South Africa. Afr J Biotechnol. 2012; 11: 10598-10604

13. Rashmi, K. S., Ravi Kumar, K. I., and Rhagyashree, H. N. Asymptomatic bacteriuria in HIV/AIDS patients: occurrence and risk associated with low CD4 counts. JEMDS. 2013; 2: 33583360 .

14. Schonwald, S., Begovae, J., and Skerk, V. Urinary tract infections in HIV disease. Int J Antimicrob Agents. 1999: 309 - 311

15. Kaplan, M. S., Wschsler, M., and Benson, M. C Urologic manifestations of AIDS. Urology. 1978; 30: $441-443$

16. Asharam, K., Bhimma, R., and Adhikari, M Human Immunodeficiency virus and urinary tract infections in children. Ann Trop Paediatr. 2003; 23: $273-277$

17. O'Regan, S., Russo, P., Lapointe, N., and Rousseau, E. AIDS and the urinary tract. J AIDS. 1990; 3: 244-

18. Ibadin, M. O., Onunu, A., and Ukoh, G. Urinary tract infection in adolescent /young adult Nigerians with acquired human immunodeficiency disease in Benin City. J Med Biomed Res. 2006; 5: 55-60.

19. Akinsete, A. M., and Ezeaka, C. Prevalence and risk factors of asymptomatic bacteriuria among children living with HIV in Lagos, Nigeria. Pan Afr Med J. 2018; 31: 181

20. Inyang-Etoh, P. C., Udofia, G. C., Alaibe, A. A., et al. Asymptomatic bacteriuria in patients on antiretroviral drug treatment in Calabar. J Med Sci. 2009; 9 (6): 270-275.

21. Skrzat-Klapaczyńska, A., Matłosz, M., Bednarska, A., Paciorek, M., Firlag-Burkacka, E., Horban, A., and Kowalska, J. D. Factors associated with urinary tract infections among HIV-1 infected patients. PLoS One. 2018; 13 (1): e0190564.

22. Kanu, A. M., Mgbajiaka, N., and Abadom, N. Prevalence of urinary tract infection among HIV patients in Aba, Nigeria. Int J Inf Dis. 2016; 45 (1): 229.

23. Kemajou, T. S., Ajugwo, A. O., Oshoma, C. E., and Enabulele, O. I. Antibiotic Resistance of Bacterial Isolates from HIV Positive Patients with Urinary Tract Infection (UTI) in PortHarcourt, Nigeria. J AIDS Clin Res. 2016; 7: 594.

24. Dondo, V., Mujuru, H. A., Nathoo, J. K., Chirehwa, 
M., and Mufandaedza, Z. Renal abnormalities among HIV-infected, antiretroviral naive children, Harare, Zimbabwe: a cross-sectional study. BMC Pediatrics. 2013; 13: 75

25. Nilima, K. R., Gafencu, I. M., Doros, G., Thanki, C. N., Lesovici, M., and Serban, M. Rena Consequences in HIV Infected Children. Jurnalul Pediatrului. 2009; XII: 45-46.

26. Iduoriyekemwen, N. J., Sadoh, W. E., and Sadoh, A. E. Asymptomatic Bacteriuria In HIV positive Nigerian children. JMBR. 2012; 11 (1): 88-94

27. Sheyin, Z. S., Olowolafe, C. O., Essien, U. C. Shindang, J., Ede, F. R., and Bigwan, E. I. Prevalence of Urinary Tract Infection in HIV Patients on Antiretroviral Drugs in Jos Metropolis, Nigeria. World J of Pub HIth. 2018; 3 (2): 57-60.

28. Imamura, A. Approach to opportunistic illness in the HAART era. Nihon Rinsho. 2002; 60 (4): 757 762.

29. Hoepelman, A., Van Buren, M., Van De Broek, P. J. Bacteriuria in men infected with Human Immunodeficiency Virus-1 is related to their immune status (CD4+ cell count). AIDS. 2012; 6 (2): $179-184$

30. Klapaczyńska, A. S., Matłosz, B., Bednarska, A., Paciorek, M., Firlag-Burkacka, E., Horban, A., and Kowalska, J. D. Factors associated with urinary tract infections among HIV-1 infected patients. PLoS One. 2018; 13 (1): e0190564.

31. Okechukwu, A. A., and Amajuoyi, F. I. First and Second Line Highly Active Anti-Retroviral Therapy Failure in HIV Infected Nigerian Children at University of Abuja Teaching Hospital Gwagwalada, Nigeria. HIV Clin Scientific Res. 2015; 2 (2): 049-054.

32. Oladeinde, B. H., Omoregie, R., Olley, M., and Anunibe, J. A. Urinary tract infection in a rural community of Nigeria. N Am J Med Sci. 2011; 3 (2): 75-77.

33. Sheyin, Z. S., Olowolafe, C, O, Essien, U. C. Shindang, J., Ede, F. R., and Bigwan, E. I Prevalence of Urinary Tract Infection in HIV Patients on Antiretroviral Drugs in Jos Metropolis, Nigeria. World J of Pub HIth. 2018; 3 (2): 57-60.

34. Kennedy, T. Rudolph's Pediatrics, 21st Ed, 166773. Mc-Graw-Hill, New York, 2003.

35. Holloway, J. I., Joshi, N., and O'Bryan, T. Positive urine nitrite test: an accurate predictor of absence of pure enterococcal bacteriuria. South Med J. 2009; 93 (7): 681-682.

36. Jaun, A. M., Catalina, M., Eduardo, G., et al. Haematuria: the forgotten CKD factor? Nephrol Dial Transplant. 2012; 27 (1): 28-34. 